\title{
Regional genetic differentiation among populations of Cladocora caespitosa in the Western Mediterranean
}

\author{
Pilar Casado-Amezúa • Diego K. Kersting • \\ José Templado $\cdot$ Annie Machordom
}

Received: 1 October 2013/ Accepted: 25 July 2014

(C) Springer-Verlag Berlin Heidelberg 2014

\begin{abstract}
Cladocora caespitosa is the only reef-forming zooxanthellate scleractinian in the Mediterranean Sea. This endemic coral has suffered severe mortality events at different Mediterranean sites owing to anomalous summer heat waves related to global climate change. In this study, we assessed genetic structure and gene flow among four populations of this species in the Western Mediterranean Sea: Cape Palos (SE Spain), Cala Galdana (Balearic Islands), Columbretes Islands, and L'Ametlla (NE Spain). The results obtained from Bayesian approaches, $F_{\mathrm{ST}}$ statistics, and Bayesian analysis of migration rates suggest certain levels of genetic differentiation driven by high levels of selfrecruitment, a fact that is supported by egg-retention mechanisms. Conversely, genetic connectivity among distant populations, even if generally low, seems to be related to sporadic dispersal events through regional surface currents linked to the spawning period that occurs at the end of summer-beginning of autumn. These features, together with
\end{abstract}

Communicated by Biology Editor Dr. Stephen Swearer

Electronic supplementary material The online version of this article (doi:10.1007/s00338-014-1195-5) contains supplementary material, which is available to authorized users.

P. Casado-Amezúa

Alfred Wegener Institute, Helmholtz Centre for Polar and Marine Research, Am Alten Hafen 26, 27568 Bremerhaven, Germany

P. Casado-Amezúa $(\bowtie) \cdot$ J. Templado $\cdot$ A. Machordom Museo Nacional de Ciencias Naturales (MNCN-CSIC), C/José Gutiérrez Abascal, 2, 28006 Madrid, Spain

e-mail: p.casadoamezua@gmail.com

D. K. Kersting

Departamento d'Ecologia, Universitat de Barcelona (UB), Av. Diagonal 643, 08028 Barcelona, Spain a certain isolation of the Columbretes Islands, could explain the regional genetic differentiation found among populations. These results help to better understand population structure and connectivity of the species and will serve as an approach for further studies on different aspects of the biology and ecology of $C$. caespitosa.

Keywords Microsatellites - Genetic differentiation . Broadcast spawning coral $\cdot$ Self-recruitment .

Oceanographic barriers

\section{Introduction}

The Mediterranean Sea is a semi-enclosed sea that has been characterized as a "miniature ocean" responding quickly to changes in temperature and increases in extreme events (Lejeusne et al. 2009). Global climate change, in synergy with other disturbances such as water pollution, coastal development, massive algal blooms, pathogenic organisms, and invasive species, among others, is expected to have significant effects on Mediterranean biodiversity in the near future (Lejeusne et al. 2009; Templado 2014). For over a decade, mass mortality events have recurrently impacted Mediterranean benthic communities owing to prolonged heat waves that affect some emblematic sessile invertebrates (Cerrano et al. 2000; Perez et al. 2000; Garrabou et al. 2009; Lejeusne et al. 2009). The scleractinian coral Cladocora caespitosa (Linnaeus, 1767) is among these affected species and mortalities of its reefs have been recorded, including those in the Adriatic Sea (Kružić et al. 2012), Gulf of La Spezia (Rodolfo-Metalpa et al. 2005), and Columbretes Islands where over $50 \%$ of the coral cover has been affected by necrosis during the last decade (Kersting et al. 2013a). 
Cladocora caespitosa is the sole Mediterranean colonial and zooxanthellate scleractinian with reef-forming capacity (Morri et al. 1994). It is considered a relict species from the subtropical late Pliocene and Quaternary periods (Kühlman et al. 1991; Peirano et al. 2009) according to the fossil record (e.g., Fornós et al. 1996; Bernasconi et al. 1997; Aguirre and Jiménez 1998). Currently, the total abundance of C. caespitosa is reduced overall in the Mediterranean. The remaining populations are patchily distributed across the entire Mediterranean Basin, and only a few living banks (large colonies more than $1 \mathrm{~m}$ high and covering several square meters in surface area) and/or beds (groups of small globose to hemispherical colonies) of this coral have been recorded (Laborel 1961; Schiller 1993; Morri et al. 1994; Peirano et al. 1999; Kružic and Benkovic 2008; Özalp and Alparslan 2011; Kersting and Linares 2012). The decrease of the geographical range of C. caespitosa reefs in the Mediterranean with respect to its fossil distribution prompted Augier (1982) to include this coral in a list of marine species under extinction risk. Furthermore, this regression is still in progress, enhanced by mortality events that the coral has suffered in recent decades together with other threats such as the presence of invasive algal species (Kružic et al. 2008b; Kersting et al. 2014a).

The ability of marine populations to resist and recover from environmental disturbances depends in part on population connectivity and recruitment processes, which contribute to the addition of new individuals to populations and therefore to population resilience of marine organisms (Caley et al. 1996), particularly corals (Adjeroud et al. 2007) including $C$. caespitosa in the Mediterranean (Kersting et al. 2014b). To improve our knowledge on the recovery potential of this bioconstructive species, a better understanding of the resilience of its populations is needed. Population genetic studies enable the estimation of the structure and connectivity of populations and the identification of associated processes, such as self-recruitment, barriers to gene flow, introgression, isolation, and fragmentation of populations (Baums 2008). It should be noted that these features are linked to species' life history traits, such as species' dispersal capacity at each stage of its life cycle, and their interaction with associated biotic and abiotic factors (DiBacco et al. 2006). The reproductive ecology of $C$. caespitosa has been examined from populations in the Adriatic Sea (Kružic et al. 2008a) and Western Mediterranean Sea (Kersting et al. 2013b). In the Adriatic Sea, the colonies of $C$. caespitosa are hermaphroditic and spawning occurs at the beginning of summer, which coincidences with rising seawater temperatures (Kružic et al. 2008a). By contrast, in the Western Mediterranean, this coral is regarded as gonochoric with spawning occurring at the end of summer (August to October) when seawater temperatures are declining (Kersting et al. 2013b). In situ observations in the Adriatic Sea indicate that the release of male and female gametes is asynchronous for each hermaphroditic colony. Eggs were released by the polyps in a mucous coating, also called "clumps" that bound the eggs together, while sperm were freely released in sperm bundles (Kružic et al. 2008a). According to the authors, fertilization may be enhanced by synchronous spawning and egg retention on the colony surface. In addition, dispersal among populations might be affected by physical barriers (hydrographic fronts, upwelling systems, eddies, or counter currents), or enhanced by oceanographic features such as global and local water currents or rafting events (Pineda et al. 2007).

Taking into account all of the above, the main aim of this study was to examine the genetic structure and connectivity patterns of some populations of the Mediterranean reef-forming coral $C$. caespitosa from the Western Mediterranean Basin. The egg-retention mechanisms described for this coral may increase self-recruitment, as evidenced by the distribution and recruitment patterns of some of its populations (Kersting and Linares 2012; Kersting et al. 2014b). Therefore, it is hypothesized that populations of $C$. caespitosa in the Western Mediterranean basin may display high levels of self-recruitment, showing different levels of genetic differentiation between them.

\section{Materials and methods}

\section{Study area and sample collection}

Colonies of $C$. caespitosa were sampled at four localities in the western Mediterranean Sea: Cape Palos (Murcia, SE Spain), Cala Galdana (Menorca, Balearic Islands), Columbretes Islands (at the edge of the continental shelf $60 \mathrm{~km}$ off the nearest coast of E Spain), and L'Ametlla (Tarragona, NE Spain; Table 1; Fig. 1).

At each sampling locality, individual polyps from 13 to 37 colonies were collected at depths between 10 and $15 \mathrm{~m}$, using SCUBA diving. Sampled colonies were randomly chosen within a given area of $300-500 \mathrm{~m}^{2}$, with a minimum distance between colonies of 1-2 $\mathrm{m}$ to avoid sampling the same colony twice. To minimize damage to the sampled colonies, one or two polyp tips were carefully detached from one of the edges of each colony with a hammer and chisel and placed into labeled bags. Samples were stored in vials of absolute ethanol until laboratory analyses. It should be noted that the small number of samples from Cape Palos is because of the low number of colonies found in the area.

DNA extraction, microsatellite amplification and genotyping

Total DNA was extracted from a total of 108 polyps using a Qiagen BioSprint IT 15DNA Blood Kit (Table 1). Eight 
Table 1 Data of sampled populations of Cladocora caespitosa

\begin{tabular}{llllllllllll}
\hline Basin & Population & Location & $N$ & $N \mathrm{~g}$ & $N_{\mathrm{a}}$ & $P_{\mathrm{a}}$ & $N_{\mathrm{S}(24)}$ & $P_{\mathrm{S}(24)}$ & $H_{\mathrm{o}}$ & $H_{\mathrm{e}}$ & $F_{\mathrm{IS}}$ \\
\hline $\begin{array}{l}\text { Algerian } \\
\text { Basin }\end{array}$ & Cape Palos & $37^{\circ} 34^{\prime} 34.98^{\prime \prime} \mathrm{N}$ & 13 & 13 & $5.0(1.3)$ & $0.5(0.2)$ & $4.9(1.3)$ & $0.8(0.3)$ & $0.528(0.085)$ & $0.511(0.088)$ & $-\mathbf{0 . 0 3 5}$ \\
Balearic Sea & Cala Galdana & $0^{\circ} 46^{\prime} 32.64^{\prime \prime} \mathrm{W}$ & & & & & & & & & \\
& & & & & & & & \\
& $3^{\circ} 59^{\prime} 31.62^{\prime \prime} \mathrm{N}$ & 37 & 33 & $5.8(1.6)$ & $0.6(0.3)$ & $4.4(1.1)$ & $0.4(0.1)$ & $0.543(0.095)$ & $0.543(0.095)$ & 0.002 \\
Balearic Sea & Columbretes & $39^{\circ} 53^{\prime} 38.55^{\prime \prime} \mathrm{N}$ & 28 & 27 & $5.9(1.5)$ & $1.5(0.7)$ & $4.4(1.1)$ & $1.0(0.5)$ & $0.412(0.098)$ & $0.444(0.107)$ & $-\mathbf{0 . 0 7 3}(0.057)^{*}$ \\
& Islands & $0^{\circ} 41^{\prime} 10.37^{\prime \prime} \mathrm{E}$ & & & & & & & & & \\
Balearic Sea & L'Ametlla & $40^{\circ} 50^{\prime} 27.20^{\prime \prime} \mathrm{N}$ & 30 & 28 & $4.1(1.1)$ & $0.1(0.1)$ & $3.5(0.9)$ & $0.1(0.1)$ & $0.413(0.107)$ & $0.452(0.099)$ & $\mathbf{0 . 0 8 7}(-0.046)$ \\
& & $0^{\circ} 44^{\prime} 58.90^{\prime \prime} \mathrm{E}$ & & & & & & & & &
\end{tabular}

$N$ number of collected and analyzed individuals, $\mathrm{Ng}$ number of unique multilocus genotypes, $\mathrm{Na}$ average number of alleles per population, $P_{a}$ number of private alleles per population, $N_{\mathrm{S}(24)}$ : mean allelic richness standardized to the smallest sample size, $P_{\mathrm{S}(24)}$ : number of private alleles per population standardized to the smallest sample size, $H_{\mathrm{o}}$ and $H_{\mathrm{e}}$ mean observed and expected heterozygosities, $F_{\mathrm{IS}}$ inbreeding coefficient. Bold $F_{\mathrm{IS}}$ significant values of probability estimates.

* Significant $F_{\text {IS }}$ values after Brookfield (1996) null allele correction

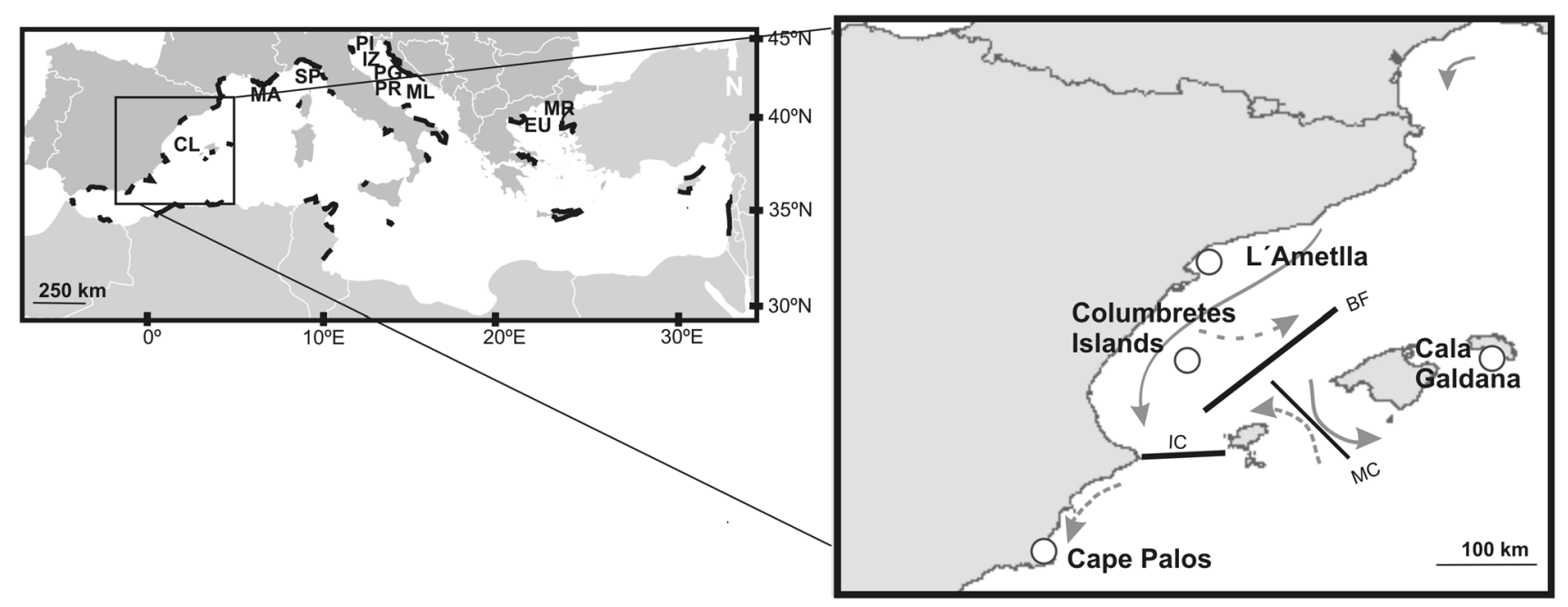

Fig. 1 Left panel schematic map showing the distribution range of Cladocora caespitosa in the Mediterranean as well as the main known living reefs of the species. CL, Columbretes Islands (Kersting and Linares 2012); MA, Port-Cross, Gulf of Marseille (Zibrowius 1980); SP, Gulf of La Spezia (Morri et al. 1994); PI, Bay of Piran (Schiller 1993); IZ, Iz Island; PG, Pag Island; PR, Prvic; ML, Mjlet (Kružić and Benkovic 2008); EU, Eubeé, Gulf of Atalante (Laborel 1961);

microsatellite loci, specifically developed for C. caespitosa (Casado-Amezúa et al. 2011), were amplified with eight primer pairs including a fluorescently-labeled forward primer and following the PCR conditions described in Casado-Amezúa et al. (2011). PCR products were visualized with an automated sequencer (ABI PRISM 3730 DNA Sequencer, Applied Biosystems) with the GeneScan-500 (LIZ) internal size standard. Electropherograms were analyzed for allele scoring with GeneMapper software 3.0 (Applied Biosystems).

\section{Data analysis}

The possibility of the presence of clone mates (i.e., individuals with the same genotypes) was estimated from the
MR, Marmara Sea (Özalp and Alparslan 2011). Right panel sampled populations of $C$. caespitosa. A schematic of sea-surface currents and main oceanographic barriers is shown. BF: Balearic Front; IC: Ibiza Chanel; MC: Mallorca Chanel. Continuous arrows indicate main currents, discontinuous arrows indicate mesoscale currents throughout the year (modified from Ruiz et al. 2009)

allele frequencies observed in the multilocus genotypes in each population using GenAlEx (Peakal and Smouse 2006). Additionally, the probability that the two randomly chosen individuals in a population had identical genotypes by chance was calculated with the Probability of Identity $\left(P_{\mathrm{ID}}\right)$ index using GeneAlEx software. This index resulted in a low average value across populations of $3.04 \times 10^{-5}$. Therefore, because individuals that showed identical genotypes could be considered clones, each distinct eightlocus genotype in the data set was included for statistical analysis.

Linkage disequilibrium (LD) was tested among all pairs of loci at each of the sampled locations with a permutation test using GenePop version 3.4 (Raymond and Rousset 1995). Analysis of significance was tested with the Markov 
Chain Monte Carlo (MCMC; that was run using 1,000 dememorizations with 100 batches and 1,000 iterations per batch). MICRO-CHECKER v.2.2.3 software (van Oosterhout et al. 2004) was used to check for scoring errors due to stuttering, large allele dropout, and to estimate null allele frequencies.

\section{Genetic diversity}

Parameters of genetic diversity for each population and for the global sample were estimated. Allelic diversity $\left(N_{\mathrm{a}}\right)$ was quantified as the number of alleles per locus over all loci and localities using GenAlEx 6.0 software (Peakal and Smouse 2006). Allelic richness and private allelic richness were estimated with a rarefaction procedure using HP-RARE software (Kalinowsky 2005), with the minimum number of genes set at $24\left(N_{\mathrm{S}(24)} ; P_{(24)}\right)$. Analyses of departures from Hardy-Weinberg equilibrium (HWE) within populations for each locus and over all loci were quantified as the observed $\left(H_{\mathrm{o}}\right)$ and expected $\left(H_{\mathrm{e}}\right)$ heterozygosities using GenAlEx 6.0 software (Peakal and Smouse 2006). Estimations of the inbreeding coefficient, $F_{\mathrm{IS}}$, an estimate of the deficit or excess of heterozygotes, within each population for each locus and over all loci were computed with Genetix (Belkhir et al. 2004). Significance of the estimation analysis was tested with 10,000 permutations.

A step-down Bonferroni (Holm 1979) correction was applied to $p$ values in all the statistical analyses that included multiple comparisons.

\section{Inference of population differentiation}

POWSIM v4.0. (Ryman and Palm 2006) was used to estimate the statistical power provided by the microsatellite dataset for correctly testing for population genetic differentiation. The four localities sampled were used for testing allele frequency homogeneity at the eight loci and combining information for the multiple loci using Fisher's exact and chi-squared tests. Simulations were run using various combinations of $N_{\mathrm{e}}$ (effective population size) and $t$ (time since divergence), leading to $F_{\mathrm{ST}}$ values of $0.001-0.05$, reproducing the magnitude of $F_{\mathrm{ST}}$ values estimated from the data. Simulations were carried out for effective population sizes $N_{\mathrm{e}}=2,000, N_{\mathrm{e}}=5,000$ and $N_{\mathrm{e}}=10,000$ to yield $F_{\mathrm{ST}}$ values of $0.001,0.025$, and 0.05 . One thousand replicates were run, and the power of the analysis was indicated by the proportion of tests that were significant at $p<0.05$ using the respective allele frequencies at the eight loci studied.

For the measures of genetic differentiation, sample sites were used as a population unit. $F_{\mathrm{ST}}$ values between sampling localities were estimated using ARLEQUIN 3.1.1. software (Excoffier et al. 2005), and their statistical significance calculated from 10,000 bootstrap replicates (Weir and Cockerham 1984). As null alleles can induce overestimation of genetic distances (Chapuis and Estoup 2007), pairwise estimates were computed with and without correction for null alleles (Brookfield 1996).

Population genetic structure was also inferred using a Bayesian approach. The number of genetically differentiated $C$. caespitosa populations, $K$, with the highest posterior probability given the data was estimated with STRUCTURE 2.3.3 (Pritchard et al. 2000). The software was run using the admixture model under the "location prior" function (LOCPRIOR) with correlated allele frequencies. LOCPRIOR was considered the most accurate model because even while it learns from a priori assignment of individuals into populations, it does not tend to infer structure when none exists (Pritchard et al. 2000; Hubisz et al. 2009). Simulations included 20 replicated runs for $K$ values $1-10$ and a mean log probability of the data $(\ln \mathrm{P}(K))$ was calculated. The MCMC of each run consisted of 100,000 burn-in iterations followed by $1,000,000$ sampled iterations. The $\Delta K$ value is an index for deciding the probable number of genetically clustering populations. $\Delta K$ values were calculated using the method outlined in Evanno et al. (2005) as implemented on STRUCTURE Harvester (Earl and von Holdt 2012). CLUMPP v.1.1 (Jakobsson and Rosenberg 2007) was used to merge the results across the 20 runs for a given $K$. DISTRUCT v.1.1 (Rosenberg 2004) was used to visualize the results. The likelihood of the data and subsequent probabilities for the different numbers of populations were calculated with $K(1-10)$.

The influence of geographic distance on population genetic differentiation was calculated with two models: The Rousset (1997) model for two-dimensional habitats with the correlation between pairwise population linearized $F_{\mathrm{ST}}\left(F_{\mathrm{ST}} /\left(1-F_{\mathrm{ST}}\right)\right)$ and the logarithm of the geographical distance (in meters); and Slatkin (1993) model, which uses the logarithm of $\widehat{M}$ calculated separately for pairs of populations, (where $\widehat{M}=\left(1-F_{\mathrm{ST}}\right) / 4 F_{\mathrm{ST}}$ ) as a measure of similarity, versus the logarithm of the geographical distance. This parameter corresponds to the number of migrants required to account for observed genetic differences if migrants could move directly between populations. In both cases, Mantel tests (10,000 permutations) were used to assess statistical significance. The strength of the isolation by distance (IBD) relationship was quantified with the slope and intercept of genetic similarity $(\widehat{M})$ or distance (linearized $F_{\mathrm{ST}}$ ) against geographic distance. Both parameters were calculated using reduced major-axis regression (RMA) (Sokal and Rohlf 1981). Asymmetric $95 \%$ confidence intervals around the RMA regression coefficient 
were calculated with 10,000 bootstraps around individual population pairs. All the analyses were done with IBDWS software (Jensen et al. 2005). Geographical distances were measured by means of dead-reckoning distances using MatLab software.

\section{Estimation of migration rates}

We used the Bayesian model implemented in BayesAss + v1.3 (Wilson and Rannala 2003) to estimate recent migration rates $(\mathrm{m})$ among populations. The model was run under default parameters. As suggested by Baums et al. (2005) and Cibrián- Jaramillo et al. (2010), a jackknife procedure was used sequentially omitting each of the sampling localities from the migration matrix. This approach is based on the fact that particular population features, such as demographic factors (Cornuet et al. 1999; Wilson and Rannala 2003), may affect migration rates of the other localities. Thus, if a population contributes migrants, its exclusion will increase the other population's self-recruitment rates. If a population contribution is minimal for the rest of the populations, its exclusion might decrease mean self-recruitment rates. Self-recruitment migration matrices were obtained following the procedure in Baums et al. (2005), by obtaining four matrices sequentially omitting each of the sampling localities and one matrix for all of the populations. The diagonals present in the resulting matrices were summarized and compared with the overall population's matrix.

\section{Results}

A total of 108 individuals were genotyped for eight microsatellite loci. After removing identical genotypes from all populations, except Cape Palos were no identical genotypes were found, a total of 101 unique genotypes were considered for the analyses: 33 in Cala Galdana, 27 in Columbretes Islands, 28 in L'Ametlla and 13 from Cape Palos (Table 1). Linkage disequilibrium (LD) among loci was found only in three of the 28 pairwise comparisons per sampling locality $(p<0.05$ after step-down Bonferroni correction). None of the analyses were significant at the same time for all loci in all populations. Therefore, physical linkage can be rejected.

Across localities, allelic diversity $\left(N_{\mathrm{a}}\right)$ ranged from $4.1 \pm 1.1$ (L'Ametlla) to $5.9 \pm 1.5$ (Columbretes Islands; mean value \pm standard error (SE) here and hereafter) and private allelic richness from $0.1 \pm 0.1$ (L'Ametlla) to $1.5 \pm 0.7$ (Columbretes Islands; Table 1). After rarefaction, allelic diversity parameters were in the range of $3.5 \pm 0.9$ (L'Ametlla) to $4.9 \pm 1.3$ (Cape Palos) and private allelic richness from $0.1 \pm 0.1$ (L'Ametlla) to
$1.0 \pm 0.5$ (Columbretes Islands; Table 1). Departures from HWE, measured as $F_{\text {IS }}$, were not generalized over all loci in each population. In cases of heterozygote deficiencies, evidence for null alleles was checked and their frequencies were computed at each locus for each sampled site. No evidence of allelic dropout or scoring errors because of stuttering was found. The analysis detected the possibility of null alleles in locus CcL5 in Cala Galdana, Columbretes Islands, and L'Ametlla and in CcL16 in L'Ametlla, owing to an excess of homozygotes in most allele size classes. Null allele frequencies for locus CcL5 were in the range of 0.09 (Columbretes Islands) to 0.27 (L'Ametlla). However, applying the corresponding correction for null alleles (in all cases; Brookfield 1996) did not qualitatively affect the results (Electronic Supplementary Material, ESM, Table S1). Over all loci, $F_{\text {IS }}$ values were in the range of -0.035 (Cala Galdana) to 0.087 (L'Ametlla; Table 1). After null allele correction, the overall loci $F_{\text {IS }}$ value from L'Ametlla decreased; however, the value remained significant for the Columbretes Islands.

Population genetic structure and gene flow

Simulations performed with POWSIM v4.0 suggested that the statistical power of the eight microsatellites was high for detecting $F_{\mathrm{ST}}$ values of 0.01 (91 and $88 \%$ probabilities according to the chi-square test and Fisher's test, respectively), and 0.05 (98.2 \% probability according to the chisquare test and Fisher's test). The $\alpha$ error (type I: proportion of false significances) was also estimated by performing simulations of no divergence among populations (i.e., setting $t=0$ ). This resulted in a proportion of $1 \%$ significance, which is lower than the intended value of $5 \%$.

The Bayesian clustering analysis detected the highest likelihood $(\operatorname{Ln} P(K)=-1,760.83 \pm 46.83)$ with $K=5$. The modal value of $\Delta K$ (Evanno et al. 2005) is shown at $K=5$, showing genetic differentiation among the studied populations nonetheless with certain levels of admixture. The highest proportion of membership of each sampled population within each cluster defined by STRUCTURE corresponded to (Fig. 2): Cluster 1-Columbretes Islands, Cluster 2-L'Ametlla, Cluster 3-Cala Galdana, Cluster 4-Cape Palos. The fifth cluster (Cluster 5) was formed from individuals of the four sampled localities; however, the population of L'Ametlla contributed most to this cluster (Fig. 2).

Pairwise $F_{\text {ST }}$ values (Table 2) ranged from 0.012 (Cape Palos-L'Ametlla) to 0.051 (Cala Galdana-Columbretes Islands). After correction for null alleles, no significant differences between pairwise $F_{\mathrm{ST}}$ values and pairwise $F_{\mathrm{ST}}$ values corrected for null alleles were observed ( $t$ test, $p=0.560$ ). Therefore, we assume that the presence of null alleles did not affect the analyses. The highest $F_{\mathrm{ST}}$ values were found in relation to pairwise comparisons of the 
Fig. 2 Bar plot of the Bayesian clustering analyses performed with STRUCTURE 2.3.3. software. Cluster 1 is represented by green, cluster 2 by violet, cluster 3 by pink cluster 4 by yellow and cluster 5 by red. The values above the figure indicate the proportion of membership of each pre-defined population (i.e., sampled locality) in each of the five clusters

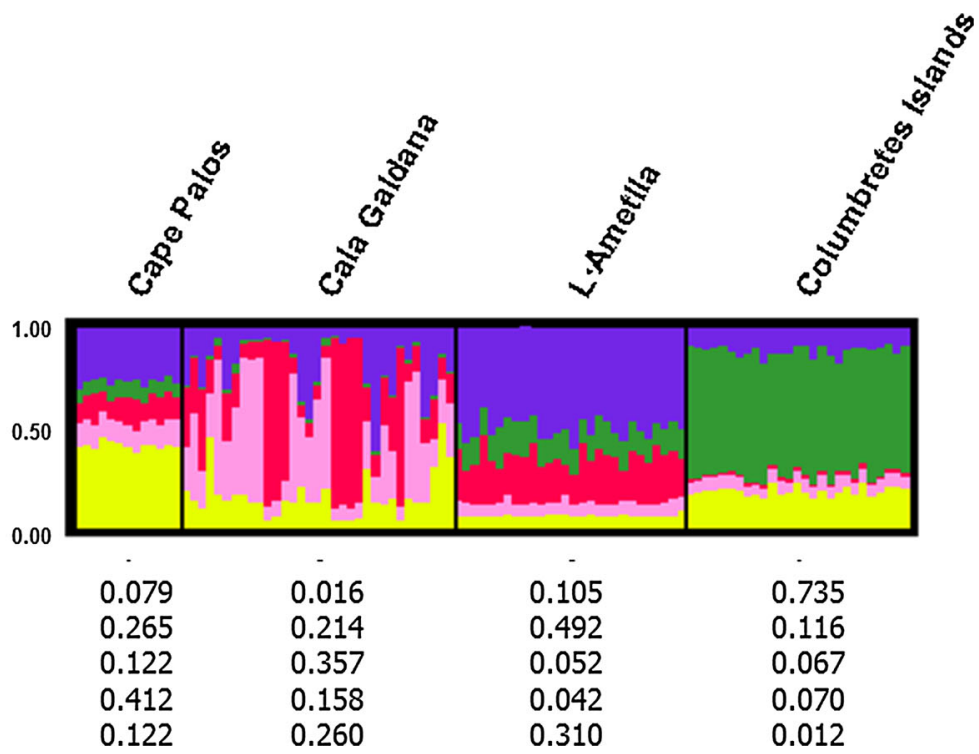

Table 2 Pairwise $F_{\mathrm{ST}}$ values between populations

\begin{tabular}{llll}
\hline & $\begin{array}{l}\text { Cape } \\
\text { Palos }\end{array}$ & $\begin{array}{l}\text { Cala } \\
\text { Galdana }\end{array}$ & $\begin{array}{l}\text { Columbretes } \\
\text { Islands }\end{array}$ \\
\hline Cala Galdana & 0.016 & & \\
Columbretes Islands & $\mathbf{0 . 0 2 8}$ & $\mathbf{0 . 0 5 1}$ & \\
L'Ametlla & 0.012 & $\mathbf{0 . 0 2 0}$ & $\mathbf{0 . 0 2 7}$ \\
\hline
\end{tabular}

Significant values after step-down Bonferroni correction are highlighted in bold $(p<0.01)$

Columbretes Islands and the other localities (Table 2), with slight but significant or non-significant values found among the other populations. Neither of the two isolation by distance models, showed significant relationships between genetic and geographic distances: Slatkin model: $F_{\mathrm{ST}} /(1-$ $\left.F_{\mathrm{ST}}\right)=0.025-0.037 \quad \log \quad($ dist $), \quad R^{2}=0.20, \quad p=0.80$; Rousset model: $\log (M)=1.35-6.24 \log$ (dist), $R^{2}=0.28$, $p=0.95$.

Self-recruitment rates showed values of $0.69 \pm 0.02$ in Cape Palos to $0.90 \pm 0.02$ in L'Ametlla. Recent migration rates were high only between the population of L'Ametlla and the others, as indicated with immigration rates of ca. 0.3 . Migration rates between the other populations were very low $(\leq 0.04)$. Despite the overall lack of differentiation between localities, the jackknife procedure showed higher rates of self-recruitment in all the populations when excluding L'Ametlla (Table 3).

\section{Discussion}

The population structure of marine organisms reflects their historical and contemporary interaction at different spatial and temporal scales among a complex set of ecological, demographic, behavioral, oceanographic, climatic, and geological processes (Grosberg and Cunningham 2001). Past geological and ecological events, together with the corals' sexual reproductive traits and their relation to oceanographic and geomorphologic processes may explain the present genetic structure of Cladocora caespitosa. Our results suggest that the studied populations are highly dependent on self-recruitment, likely enhanced by the eggretention mechanisms of this species (Kružic et al. 2008a), all of which is reflected in this species' the distribution and recruitment patterns (Kersting and Linares 2012; Kersting et al. 2014b). On the other hand, the genetic connectivity among the populations, even if generally low, seems to be related to sporadic dispersal events through regional surface currents linked to the spawning period.

According to the Bayesian analysis, the individuals from the sampled populations are divided into four different clusters, and the gene flow of individuals from unsampled populations might result in the fifth cluster (Slatkin 2005; Hellberg 2007). The studied clusters share alleles and allelic frequencies and, therefore, are not fully isolated from each other. Even so, this analysis should be considered with caution as the performance of STRUCTURE algorithms decreases with sample size (Latch et al. 2006), such as might have occurred for the population of Cape Palos $(N=13)$. Small but highly significant $F_{\mathrm{ST}}$ values were found between the Columbretes Islands population and the others, while slight but significant or non-significant values were found among the other populations. Migration rates showed the prevalence of self-recruitment processes within each population (from $0.69 \pm 0.02$ at Cape Palos to $0.90 \pm 0.02$ at L'Ametlla). These features might be influenced by the characteristic spawning mechanism of the coral ("clumps" of eggs; Kružic et al. 2008a) 
Table 3 Migration rates of Cladocora caespitosa (mean \pm SD) among sampled populations estimated by BayesAss+

\begin{tabular}{lllll}
\hline From & & & & \\
\hline Into & Cape Palos & Cala Galdana & Columbretes Islands & L'Ametlla \\
\hline Cape Palos & $0.69 \pm 0.02$ & $0.02 \pm 0.01$ & $0.02 \pm 0.02$ & $0.27 \pm 0.03$ \\
Cala Galdana & $0.01 \pm 0.01$ & $0.70 \pm 0.01$ & $0.01 \pm 0.01$ & $0.29 \pm 0.02$ \\
Columbretes Islands & $0.01 \pm 0.01$ & $0.01 \pm 0.02$ & $0.75 \pm 0.02$ & $0.23 \pm 0.02$ \\
L'Ametlla & $0.04 \pm 0.01$ & $0.04 \pm 0.01$ & $0.01 \pm 0.01$ & $0.90 \pm 0.02$ \\
\hline
\end{tabular}

Source populations are given in columns, recipient localities in rows. Values along the diagonal are populations' self-recruitment rates

and may suggest that genetic connectivity is somehow maintained by sporadic events of gene flow among the studied populations (Hellberg et al. 2002). There is a general lack of studies regarding the behavioral mechanisms of $C$. caespitosa planulae and their relationship to environmental factors. However, with the obtained results, we assume that sporadic gene flow events might be a consequence of variable hydrodynamic conditions and of structure and continuity of rocky substrata along the coastline together with other external factors. Another possible explanation of our results could be the presence of temporal recruitment pulses, i.e., sporadic massive settlement events of larvae supplied from external sources, which might be influenced by the reproductive biology of the species coupled with extrinsic factors such as the variable current system. These pulses have been shown to be of great impact on the increase in population densities in some anthozoans and marine invertebrates (Yoshioka 1996; Connell et al. 1997; Sams and Keough 2013).

The sampled area is located in the Balearic Basin. This area is dominated by the Northern Current, which flows southwards along the Iberian Peninsula until it reaches the Ibiza Channel, where it both continues southwards and recirculates cyclonically, to a lesser or greater extent, over the Balearic Islands forming the Balearic Current (Font et al. 1990). Both currents, the Northern and the Balearic, are regarded as the motor for surface circulation of the region (Font et al. 1995). The surface layer circulation is seasonal in character. During the spring and summer, the formation of a gyre partially deflects the Northern current toward the Balearic Sea, thus lowering water flow through the Ibiza Channel. During the autumn-winter season, this gyre is less evident owing to the weaker character of the Balearic Front and the increase in intensity of the Northern Current (La Violette et al. 1990; Font et al. 1995). The relative seasonal intensities of the Northern Current and the mentioned gyre play an important role in gene flow in this region. For example, in the red gorgonian Paramuricea clavata, the seasonal gyre that occurs before the Ibiza Channel is thought to reduce southward gene flow between populations, due to the coincidence in the reproductive timing of the species (between June and
July), and the intensification of the gyre (Mokhtar-Jamaï et al. 2011). By contrast, in the case of $C$. caespitosa, our results showed that southwards gene flow is not impeded as most of the immigrants came from the area of L'Ametlla. In the fish Serranus cabrilla, it has been suggested that this barrier is directional, as gene flow moves from north to south and from the southern localities of this channel toward the Balearic Islands (Schunter et al. 2011). According to the data obtained here, this barrier also seems to act as a directional barrier for $C$. caespitosa, as the highest level of gene flow was found southwards. Therefore, north-to-south gene fluxes are much more important in magnitude than south-to-north fluxes via recirculation over the Balearic Islands. This is in concordance with the spawning period of $C$. caespitosa in the Western Mediterranean, which occurs at the end of summer-beginning of autumn (Kersting et al. 2013b), and also coincides with the increase in intensity of the Northern Current.

The population from Columbretes Islands was shown to have a certain genetic differentiation. This might also explain the excess of homozygotes found in the Columbretes Islands even after correcting for null alleles, as heterozygosity deficiencies may be caused by historical and demographic events such as selection, population mixing, and non-random mating (Luikart et al. 2003). Colonies from this population were sampled in the Illa Grossa Bay, which is a semi-enclosed $C$-shaped volcanic caldera, open to the direction of winter storm waves, in which the coral colonies form banks and beds in a mixed manner (Kersting and Linares 2012). The colonies of $C$. caespitosa in the Columbretes Islands have a highly aggregated distribution, because most of the colonies are concentrated inside the volcanic caldera. This distribution has been associated with sea bottom morphology and hydrodynamic protection together with the reproductive strategies of the species (Kersting and Linares 2012). The isolated location of the Columbretes Islands $(60 \mathrm{~km}$ off the nearest coast), together with the protection of the bay (home to the coral banks) and the egg-retention mechanisms that may reduce dispersal, may be the causes of the differentiation of the Columbretes Islands' population from 
the other sampled populations, as previously suggested by Kersting and Linares (2012).

This is the first study dealing with the population genetics of $C$. caespitosa, a relict species in the Mediterranean Sea. The high self-recruitment levels and the low and probably intermittent connectivity found, together with the slow dynamics of the species (Kersting et al. 2014b), may indicate a reduced recovery potential from the recurrent heat wave-induced mortalities that are affecting this species (Kersting et al. 2013a). The results obtained will promote conservation plans for the populations of this coral. An adequate marine reserve network that considers source populations of the coral, such as L'Ametlla, and differentiated populations, such as those in the Columbretes Islands, should be designed. This will assure connectivity among populations and genetic diversity, as has been suggested for other anthozoans in which populations are highly maintained by self-recruitment processes in the Mediterranean, such as the red gorgonian Paramuricea clavata (Mokhtar-Jamai et al. 2011) and the orange coral Astroides calycularis (Casado-Amezúa et al. 2012). Moreover, studies on modular growth, planula behavior, dispersal abilities, and recruitment processes are recommended to better understand the population dynamics and resilience of $C$. caespitosa in the face of a changing environment, thus informing management and conservation strategies.

Acknowledgments We want to acknowledge A. Luque, M. Taviani, P. Montagna, J. Fayos, E. Serrano and A. Addamo for their help either in the field work or providing samples, and M.H. Nielsen for help on data analysis. We thank S. Young and M. Hara for English revision of grammar and style. C. Papetti helped us to improve the manuscript with suggestions on the analyses. Two anonymous reviewers and S. Swearer help to improve this manuscript. We thank the Secretaría General de Pesca Marítima (MAGRAMA) and the Columbretes Islands Marine Reserve staff for their logistical support. We thank the Spanish authorities for Environment and Fisheries, Valencia Autonomous Community and Balearic Islands Regional Government the permits for collecting the samples. This study was supported by the Autonomous Organism of National Parks (Spanish Ministry of Environment) and projects CGL2011-23306 from the Spanish Ministry of Science and Innovation, and COCONET_- "Towards COast to COast NETworks of marine protected areas (from the shore to the high and deep sea), coupled with sea-based wind energy potential"from the VII FP of the European Commission. P. Casado-Amezua is currently funded by a postdoctoral internship from the Alfred Wegener Institute for Polar and Marine Research (AWI).

\section{References}

Adjeroud M, Penin L, Carroll A (2007) Spatio-temporal heterogeneity in coral recruitment around Moorea, French Polynesia: implications for population maintenance. J Exp Mar Bio Ecol 341:204-218
Aguirre J, Jiménez AP (1998) Fossil analogues to present-day Cladocora caespitosa coral banks: sedimentary setting, dwelling community, and taphonomy (Late Pliocene, W Mediterranean). Coral Reefs 17:203-213

Augier H (1982) Inventory and classification of marine benthic biocenoses of the Mediterranean. Council of Europe (ed) Nature and Environmental Series 25:1-57

Baums IB (2008) A restoration genetics guide for coral reef conservation. Mol Ecol 17:2796-2811

Baums IB, Miller MW, Hellberg ME (2005) Regionally isolated populations of an imperiled Caribbean coral, Acropora palmata. Mol Ecol 14:1377-1390

Bernasconi MP, Corselli C, Carobene L (1997) A bank of the scleractinian coral Cladocora caespitosa in the Pleistocene of the Crati Valley (Calabria, Southern Italy): growth versus environmental conditions. Bollettino-Società Paleontologica Italiana 36:53-61

Belkhir K, Borsa P, Chikhi L, Raufaste N, Bonhomme F (2004) GENETIX 4.05, Logiciel sous windows TM pour la génétique des populations. CNRS UMR 5000. Université de Montpellier II, Montpellier: Laboratoire Génome, Populations, Interactions

Brookfield JFY (1996) A simple method for estimating null allele frequency from heterozyogote deficiency. Mol Ecol 5:453-455

Caley MJ, Carr MH, Hixon MA, Hughes TP, Jones GP, Menge BA (1996) Recruitment and the local dynamics of open marine populations. Annu Rev Ecol Syst 27:477-500

Casado-Amezúa P, Goffredo S, Templado J, Machordom A (2012) Genetic assessment of population structure and connectivity in the threatened Mediterranean coral Astroides calycularis (Scleractinia, Dendrophyllidae) at different spatial scales. Mol Ecol 21:3671-3685

Casado-Amezúa P, García-Jiménez R, Kersting DK, Templado J, Coffroth MA, Merino P, Acevedo I, Machordom A (2011) Development of microsatellite markers as a molecular tool for conservation studies of the Mediterranean reef-builder coral Cladocora caespitosa (Anthozoa, Scleractinia). J Hered 5:622-626

Cerrano C, Bavestrello G, Bianchi CN, Cattaneo-vietti R, Bava S, Morganti C, Morri C, Picco P, Sara G, Schiaparelli S, Siccardi A, Sponga F (2000) A catastrophic mass-mortality episode of gorgonians and other organisms in the Ligurian Sea (Northwestern Mediterranean), summer 1999. Ecol Lett 3:284-293

Chapuis M, Estoup A (2007) Microsatellite null alleles and estimation of population differentiation. Mol Biol Evol 24:621-631

Cibrián- Jaramillo A, Daly AC, Brenner E, Desalle R, Marler TE (2010) When North and South dońt mix: genetic connectivity of a recently endangered oceanic cycad, Cycas micronesica, in Guam using EST-microsatellites. Mol Ecol 19:2364-2379

Connell JH, Hughes TP, Wallace CC (1997) A 30-year study of coral abundance, recruitment, and disturbance at several scales in space and time. Ecol Monogr 67:461-488

Cornuet JM, Piry S, Luikart G, Estoup A, Solignac M (1999) New methods employing multilocus genotypes to select or exclude populations as origins of individuals. Genetics 153:1989-2000

DiBacco C, Levin LA, Sala E (2006) Connectivity in marine ecosystems: the importance of larval and spore dispersal. In: Crooks KR, Sanjayan M (eds) Connectivity conservation. Cambridge University Press, Cambridge, pp 185-211

Earl DA, von Holdt BM (2012) STRUCTURE HARVESTER: a web site and program for visualizing STRUCTURE output and implementing the Evanno method. Conserv Genet Resour 4:359-361

Evanno G, Regnaut S, Goudet J (2005) Detecting the number of clusters of individuals using the software STRUCTURE: a simulation study. Mol Ecol 14:2611-2620

Excoffier L, Estoup A, Cornuet JM (2005) Bayesian analysis of an admixture model with mutations and arbitrarily linked markers. Genetics 169:1727-1738 
Font J, Salat J, Julià A (1990) Marine circulation along the Ebro continental margin. Mar Geol 95:165-177

Font J, Garcialadona E, Gorriz EG (1995) The seasonality of mesoscale motion in the northern current of the western Mediterraneanseveral years of evidence. Oceanologica Acta 18:207-219

Fornós JJ, Barón A, Pons GX (1996) Arrecifes de coral hermatípicos (Cladocora caespitosa) en el relleno Holoceno de la zona de Es Grau (Menorca, Mediterráneo Occidental). Geogaceta 20:303-306

Garrabou J, Coma R, Bensoussan N, Bally M, Chevaldonné P, Cigliano M, Diaz D, Harmelin JG, Gambi MC, Kersting DK, Ledoux JB, Lejeusne C, Linares C, Marschal C, Pérez T, Ribes J, Romano C, Serrano E, Teixido N, Torrents O, Zabala M, Zuburer F, Cerrano S (2009) Mass mortality in North-western Mediterranean rocky benthic communities: effects of the 2003 heat wave. Glob Chang Biol 15:1090-1103

Grosberg R, Cunningham CW (2001) Genetic structure in the sea: from populations to communities. In: Bertness MD, Gaines S, Hay ME (eds) Marine community ecology. Sinauer Associates, Sunderland, MA, pp 61-84

Hellberg ME (2007) Footprints on water: the genetic wake of dispersal among reefs. Coral Reefs 26:463-473

Hellberg ME, Burton RS, Neigel JE, Palumbi SR (2002) Genetic assessment of connectivity among marine populations. Biol Bull 70:273-290

Holm S (1979) A simple sequentially rejective multiple test procedure. Scand J Stat 6:65-70

Hubisz M, Falush D, Stephens M, Pritchard J (2009) Inferring weak population structure with the assistance of sample group information. Mol Ecol Res 9:1322-1332

Jakobsson M, Rosenberg N (2007) CLUMPP: a cluster matching and permutation program for dealing with label switching and multimodality in analysis of population structure. Bioinformatics 23:1801-1806

Jensen JL, Bohonak AJ, Kelley ST (2005) Isolation by distance, web service. BMC Genet 6:13. V3.21. http://ibdws.sdsu.edu/

Kalinowsky ST (2005) HP-RARE: a computer program for performing rarefaction on measures of allelic diversity. Mol Ecol Notes 5:539-543

Kersting DK, Linares C (2012) Cladocora caespitosa bioconstructions in the Columbretes Islands Marine Reserve (Spain, NW Mediterranean): distribution, size structure and growth. Mar Ecol 33:427-436

Kersting DK, Bensoussan N, Linares C (2013a) Long-term responses of the endemic reef-builder Cladocora caespitosa to Mediterranean warming. PLoS One 8:e70820

Kersting DK, Teixidó N, Linares C (2014a) Recruitment and mortality of the temperate coral Cladocora caespitosa: implications for the recovery of endangered populations. Coral Reefs 33:403-407

Kersting DK, Casado C, López-Legentil S, Linares C (2013b) Unexpected patterns in the sexual reproduction of the Mediterranean scleractinian coral Cladocora caespitosa. Mar Ecol Prog Ser 486:165-171

Kersting DK, Ballesteros E, De Caralt S, Linares C (2014b) Invasive macrophytes in a marine reserve (Columbretes Islands, NW Mediterranean): spread dynamics and interactions with the endemic scleractinian coral Cladocora caespitosa. Biol Invasions 16:1599-1610

Kružić P, Benković L (2008) Bioconstructional features of the coral Cladocora caespitosa (Anthozoa, Scleractinia) in the Southern Adriatic Sea. Coral Reefs 27:125-139

Kružic P, Zuljevic A, Nokolic V (2008a) Spawning of the colonial coral Cladocora caespitosa (Anthozoa, Scleractinia) in the Southern Adriatic Sea. Coral Reefs 27:337-341

Kružić P, Zuljevic A, Nikolic V (2008b) The highly invasive alga Caulerpa racemosa var. cylindracea poses a new threat to the banks of the coral Cladocora caespitosa in the Adriatic Sea. Coral Reefs 27:441

Kružić P, Sršen P, Benković L (2012) The impact of seawater temperature on coral growth parameters of the colonial coal Cladocora caespitosa (Anthozoa, Scleracinia) in the Eastern Adriatic Sea. Facies 58:477-491

Kühlman DHH, Chitiroglou H, Koutsoubas D, Koukouras A (1991) Korallenriffe im Mittelmeer? Naturwiss Rundsch 44:316

Laborel J (1961) Sur un cas particulier de concrétionnement animal. Concrétionnement à Cladocora caespitosa $\mathrm{L}$. dans le Golfe de Talante. Rápp. pv Réun. CIESM 16:429-432

Latch EK, Dharmarajan G, Glaubitz JC, Rhodes OE Jr (2006) Relative performance of Bayesian clustering software for inferring population substructure and individual assignment at low level of population differentiation. Conserv Genet 7:295-302

La Violette PE, Tintoré J, Font J (1990) The surface circulation of the Balearic Sea. J Geophys Res 95:1559-1568

Lejeusne $\mathrm{C}$, Chevaldonné P, Pergent-Martini C, Boudouresque $\mathrm{CF}$, Pérez T (2009) Climate change effects on a miniature ocean: the highly diverse, highly impacted Mediterranean Sea. Trends Ecol Evol 25:250-260

Luikart G, England PR, Tallmon D, Jordan S, Taberlet P (2003) The power of population genomics: from genotyping to genome typing. Nat Rev Genet 4:981-994

Mokhtar-Jamaï K, Pascual M, Ledoux JB, Coma R, Féral JP, Garrabou J, Aurelle D (2011) From global to local genetic structuring in the red gorgonian Paramuricea clavata: the interplay between oceanographic conditions and limited larval dispersal. Mol Ecol 20:3291-3305

Morri C, Peirano A, Bianchi CN, Sassarini M (1994) Present day bioconstructions of the hard coral, Cladocora caespitosa (L.) (Anthozoa, Scleractinia), in the Eastern Ligurian Sea (NW Mediterranean). Biologia Marina Mediterranea 1:371-373

Özalp HB, Alparslan M (2011) The first record of Cladocora caespitosa (Linnaeus, 1767) (Anthozoa, Scleractinia) from the marmara Sea. Turk Zool Derg 35:701-705

Peakal R, Smouse PE (2006) GENEALEX 6: Genetic analysis in Excel. Population genetic software for teaching and research. Mol Ecol Notes 6:288-295

Peirano A, Morri C, Bianchi CN (1999) Skeleton growth and density patterns of the temperature, zooxanthellate scleractinain $\mathrm{Cla}$ docora caespitosa from the Ligurian Sea (NW Mediterranean). Mar Ecol Prog Ser 185:195-201

Peirano A, Kružić P, Mastronuzzi G (2009) Growth of Mediterranean reef of Cladocora caespitosa (L.) in the Late Quaternary and climate inferences. Facies 55:325-333

Perez T, Garrabou J, Sartoretto S, Harmelin JG, Francour P, Vacelet J (2000) Mass mortality of marine invertebrates: an unprecedented event in the Northwestern Mediterranean. C R Acad Sci III 323:853-865

Pineda J, Hare JA, Sponaugle SU (2007) Larval transport and dispersal in the coastal ocean and consequences for population connectivity. Oceanography 20:22-39

Pritchard JK, Stephens M, Donnelly P (2000) Inference of population structure using multilocus genotype data. Genetics 155:945-959

Raymond M, Rousset F (1995) Genepop (version 1.2): population genetics software for exact tests and ecumenicism. J Hered 86:248-249

Rodolfo-Metalpa R, Bianchi CN, Peirano A, Morri C (2005) Tissue necrosis and mortality of the temperate coral Cladocora caespitosa. Ital J Zool 72:271-276

Rosenberg NA (2004) DISTRUCT: a program for the graphical display of population structure. Mol Ecol Notes 4:137-138

Rousset F (1997) Genetic differentiation and estimation of gene flow from F-statistics under isolation by distance. Genetics 145:1219-1228 
Ryman N, Palm S (2006) POWSIM: a computer program for assessing statistical power when testing for genetic differentiation. Mol Ecol Notes 6:600-602

Ruiz S, Pascual A, Garau B, Faugère Y, Alvarez A, Tintoré J (2009) Mesoscale dynamics of the Balearic front integrating glider, ship and satellite data. J Mar Syst 78:S3-S16

Sams MA, Keough MJ (2013) Effects of early recruits on temperate sessile marine community composition depend on other species recruiting at the time. Oecologia 173:259-268

Schiller CH (1993) Ecology of the symbiotic coral Cladocora caespitosa (L.) (Faviidae, Scleractinia) in the Bay of Piran (Adriatic Sea): I. Distribution and biometry. Mar Ecol 14:205-219

Schunter C, Carreras-Carbonell J, Macpherson E, Tintore J, VidalVijande E, Pascual A, Guidetti P, Pascual M (2011) Matching genetics with oceanography: directional gene flow in a Mediterranean fish species. Mol Ecol 20:5167-5181

Slatkin M (1993) Isolation by distance in equilibrium and nonequilibrium populations. Evolution 47:264-279

Slatkin M (2005) Seeing ghosts: the effect of unsampled populations on migration rates estimated for sampled populations. Mol Ecol 14:67-73
Sokal RR, Rohlf FJ (1981) Biometry, 2nd edn. WH Freeman \& Co., New York

Templado J (2014) Future trends of Mediterranean biodiversity. In: Goffredo S, Dubinsky Z (eds) The Mediterranean Sea: Its history and present challenges. Springer, New York, pp 479-498

van Oosterhout C, Hutchinson WF, Wills DPM, Shipley P (2004) MICROCHECKER: software for identifying and correcting genotyping errors in microsatellite data. Mol Ecol Notes 4:535-538

Weir BS, Cockerham CC (1984) Estimating F-statistics for the analysis of population structure. Evolution 38:1358-1370

Wilson GA, Rannala B (2003) Bayesian inference of recent migration rates using multilocus genotypes. Genetics 163:1177-1191

Yoshioka PM (1996) Variable recruitment and its effects on the population and community structure of shallow-water gorgonians. Bull Mar Sci 59:433-443

Zibrowius H (1980) Nouvelles données sur la distribution de quelques scléractiniaires "méditerranéens" à l'est et à l'ouest du détroit de Gibraltar. Rapports et Procès- Verbaux des Réunions-Commission Internationale pour l'Exploration Scientifique de la Mer Mediterranée Monaco 28:307-309 